\title{
ПАКТ ОБ ЭКОНОМИЧЕСКИХ, СОЦИАЛЬНЫХ И КУЛЬТУРНЫХ ПРАВАХ.
}

\author{
В. И. К у 3 н е ц о В*
}

Экономические, социальные и культурные права принадлежат к так называемому второму поколению (после гражданских и политических) прав человека. Их появление в международно- правовьх документах практически единодушно связывается с Октябрьской революцией в России и внешнеполитической активностью Советского Союза.

K указанной категории прав относятся: право на труд и на справедливые и благоприятные условия труда, право на создание профсоюзов и их свободное функционирование, включая право на забастовки, право на социальное обеспечение, включая социальное страхование, право на охрану и помощь семье, матерям и детям, право на достаточный жизненньй уровень, право на наивысший достижимый уровень физического и психического здоровья, право на образование, право на участие в культурной жизни и некоторые дүугие права.

Основным юридическим источником указанных прав является Международный пакт об экономических, соџиальньх и культурньх правах 1966 г. (ратифицирован Советским Союзом 18 сентября 1973 г.). Пакт вступил в силу 3 января 1976 г. и к настояшему времени в нем участвует свьпше 130 государств. К другим юридическим источникам можно отнести конвенции и рекомеңдации МОТ, документы ЮНЕСКО, ВОЗ и ряда других международных организаций, действующих в соответствующих областях.

Пакт возложил на Экономический и Социальный Совет ООН (ЭКОСОС) задачу по рассмотрению докладов, которые государства-участники должны периодически представлять в ООН (так называемые первоначальный и периодические доклады) и которые должны содержать информацию о том, какие шаги приняты государствами-участниками в целях поошрения и защиты экономических, социальных и культурных прав, а также о прогрессе, достигнутом ими в деле обеспечения этих прав.

В 1978 г. ЭКОСОС создал сессионную рабочую группу в составе 15 членов для оказания ему помощи при рассмотрении докладов. В 1982 г. рабочая группа, ранее назначавшаяся пред-

* Профессор, доктор юридических наук, заслуженный деятель науки Российской Федерации, эксперт Комитета ООН по экономическим, социальным и кульгурным правам. 
седателем ЭКОСОС, стала выборным органом правительственных экспертов по правам человека. В 1985 г. ЭКОСОС преобразовал эту рабочую группу в Комитет по экономическим, социальным и культурным правам в составе 18 членов-экспертов, которые имеют признанный авторитет в области прав человека и которые выступают в Комитете не как представители своих государств, а в личном качестве.

Комитет высказывает рекомендации и замечания общего порядка по самому Пакту и по вопросам, которые возникают в связи с Пактом. Сам Комитет так сформулировал собственную задачу: "Комитет стремится путем составления своих замечаний общего порядка сделать опьт, накопленный на настоящий момент в результате рассмотрения этих докладов, доступным для всех государств-участников с тем, чтобы содействовать дальнейшему выполнению ими Пакта; обратить внимание государств-членов на недостатки, вскрытые во многих докладах; предложить улучшение процсдуры предоставления докладов и активизировать деятельность соответствуюших государств-участников, международньх организащий и специализированных учреждений, направленную на прогрессивное и эффективное обеспечение полного осуществления прав, признаваемьх Пактом" (см. "Права человека. Комитет по экономическим, социальным и культурным правам. Изложение Фактов № 16").

Всеобщая декларация прав человека впервые соединила в своем тексте гражданские и политические права с экономическщми, социальными и культурными правами. За 50 лет, истекших после приятия Всеобщей декларацин связь между двумя указанными категориями прав описывалась по разному: кто-то считал, что эти права взаимосвязаны, кто-то говорил о взаимозависимости, другие утверждали, что они неделимы.

С друтой стороны, в западной литературе нередко можно встретить утверждение, что экономическое, социальные и культурные права в отличие от гражданских и политических прав носят не юридически обязательный, а всего лишь "программный” характер, представляют собой good will (доброе пожелание) участников, цель, к которой они должны стремиться.

В преамбуле к Международному пакту об экономических, социальньх и культурньх правах признается, “что согласно Всеобщей декларации прав человека идеал свободной человеческой личности, свободной от страха и нужды, может быть осуществлен, только если будут созданы такие условия, при которьх каждый может пользоваться своими экономическими, социальными и культурными правами, так же как и свонми гражданскими и политическими правами". 
В наши дни этот принцип признается практически повсеместно, он многократно подтверждался Генеральной Ассамблеей, Экономическим и Социальным Советом, Комиссией по правам человека, в двусторонней и многосторонней договорной практике государств. Взаимозависимость, взаимосвязанность и неделимость всех категорий прав человека нашла авторитетное подтверждение в ходе работы второй Всемирной конференции по правам человека, прошедшей в Вене в 1993 г. Большинство исследователей и практиков правозащитного движения считают абсолютно беспочвенными утверждения (кстати, наиболее часто звучашие в США), что осуществление экономических, социальньг и культурньг прав может быть только прямым следствием осуществлениям гражданских и политических прав.

Разумеется, уважение гражданских и политических прав является непременным условием реализации всех прав человека. Однако, не менее ясным должно быть то, что демократия и стабильное развитие не могут существовать сколь-нибудь долго в условиях хронической бедности и игнорирования насущньх нухд людей.

Тот факт, что пятая часть населения в мире страдает от голода, болезней и неграмотности сам по себе дает основания утверждать, что в данном случае речь идет о массовом нарушении эконөмических, социальных и культурных прав человека. Тем не менее, нарушения грахданских и политических прав по-прежнему считаются гораздо более серьезньми и нетерпимыми, чем массовое отрицание экономических, социальньх и культурньх прав.

Совсем не случайно в докладе о работе ООН, который был представлен Генеральной Ассамблее на ее сорок седьмой сессии Генеральный секретарь Организации отметил: “Политический прогресс и экономическое развитие неразделимы: обе эти цели в одинаковой степени важны и должны доститаться параллельно. Политическая стабильность необходима для выработки эффективной экономической политики, но в то же время... заметное ухудшение экономической ситуации может привести к возникновению серьезньх политических разногласий” (А/47/1, пункт 64).

Надо признать, что вопрос о природе обязательств, которые приняли на себя государства-участники Международного пакта об экономических, социальных и культурньх правах нельзя отнести к категории простых.

Прежде всего, необходимо сознавать, что обязательства государств-участников по Пакту включат в себя то, что на языке ООН называется обязательствами поведения и обязательствами результата. Это связано с тем, что в Пакте признается наличие факторов, ограничивающих возможности государств по выпол- 
нению своих обязательств, например, недостаточность имеюшихся материальных ресурсов.

Исходя из этого в Пакте предусматривается постепенное осуществление прав, для реализации которьх требуются значительные материальные ресурсы (обязательства цели). Однако. Пакт возлагает на государства-участников и различного рода обязательства безотлагательного характера (обязательства результата).

Одно из этих обстоятельств, зафиксированньх в п. 1 ст. 2 Пакта заключается в том, что государства "обязуются гарантировать", что соответствуюшие права "будут осуществляться без какой бы то ни было дискриминации...”. Необходимость избегать дискриминации проходит красной нитью через все международные документы по правам человека. На это же чаще всего обрашают внимание в органах $\mathrm{OOH}$, рассматривающих периодические доклады государств 0 ходе выполнения ими своих обязательств по соответствующим пактам и конвенциям.

Вторым таким обязательством является обязательство государств-участников "принимать меры", причем это обязательство не оговаривается каким-либо образом и не ограничивается какими-либо соображениями. Это означает только одно: хотя полное осуществление соответствующих прав может достигаться постепенно, меры по осушествлению этой цели должны быть приняты в течение разумно короткого промежутка времени после вступления Пакта в силу для соответствуюшего государства; эти меры должны быть конкретными и как можно более четко нацеленными на выполнение обязательств, признанньх в Пакте.

Комитет по экономическим, социальным и культурным правам в своем общем комментарии к п. 1 ст. 2 Пакта( пятая сессии, 1990 г.) обратил внимание государств-участников на рекомендованные методы и способы, с помощью которых можно выполнять обязательства по Пакту. Ими являются "все надлежащие способы, включая, в частности, принятие законодательных мер". В таких областях как здравоохранение, образование, охрана материнства и детства законодательство может оказаться необходимым условием для достижения цели. Бесспорно, что наличие солидной законодательной базы является непременным условием эффективной борьбы с дискриминацией.

Вместе с тем, принятие законодательньх мер не исчерпывает обязательства государств-участников. Фраза "всеми надлежашими способами” обязывает государства всякий раз решать какие способы в данных обстоятельствах и применительно к конкретным правам являются "надлежашими".

Другим таким способом, помимо законодательств, может 
быть предоставление средств судебной защиты в отношении прав, которые в соответствии с национальной правовой системой могут рассматриваться в суде. Рассматривая в мае 1997 г. третий периодический доклад России, Комитет по экономическим, социальным и культурным правам отметил в качестве одного из позитивньх аспектов меры, принимаемые в стране по реформе судебной системы и укреплению судебной власти.

Особого комментария требует положение Пакта, накладывающее на участников обязательство “обеспечить постепенно полное осуществление признаваемых в настоящем Пакте прав”. "Постепенность" означает здесь признание того объективного факта, что полное осуществление всех экономических, социальных и культурньх прав не может быть достигнуто за короткий промежуток времени. Последнее ни в коем случае не означает, что данное обязательство лишено всякого смысла. Наоборот, Пакт в данном случае устанавливает обязательство в отношении как можно более быстрого и эффективного продвижения к цели, а любой регресс в этой области, какими бы причинами он не вызывался, как правило, становится предметом тщательного рассмотрения в органах ООН, действуюших в сфере зашиты прав человека.

Например, при обсуждении упомянутого выше третьего периодического доклада России Комитет отметил, что резкое падение внутреннего валового продукта, нарушение налаженньх торговых связей, превышение государственных расходов над налоговыми поступлениями и другие подобные причины ослабили "способность государства-участника выделять достаточные ассигнования на социальные нужды” (п. 18).

Комитет по экономическим, соџиальным и культурным правам признает в соответствуюших случаях (Россия не стала исключением), что осуществление программ по перестройке экономики нередко связано с принятием довольно жестких мер. Однако, в этих условиях еще большее значение приобретают усилия по защите социально-экономических прав человека. Такой подход требует, чтобы зашита прав беднейших и наиболее уязвимых слоев населения стала одной из важных целей перестройки экономики.

В частности, применительно к России Комитет рекомендовал "усилить поддержку тех, кто живет за чертой бедности, а также выделить надлежащие финансовые ресурсы, с тем, чтобы они могли жить в достойньх условиях. Необходимо предпринять такие же усилия в интересах пенсионеров, многие из которьх испытывают серьезные финансовые трудности. Комитет считает, что усилия по обеспечению адресности расходов на социальное 
обеспечение тех, кто действительно в нем нуждается, с конечной целью предоставления им дополнительных ресурсов, являктся правильной стратегией" (п. 42).

На основе более чем десятилетнего опыта рассмотрения докладов государств-участников Комитет пришел к выводу, что на каждом государстве-участнике лежит обязательство обеспечить осуществление кахдого из социально-экономических прав человека хотя бы на минимальном уровне. Если в государстве значительное число лиц лишены основных продуктов питания, элементарной первичной медицинской помоши, образования или жилья, такое государство может рассматриваться как не выполняющее своих обязательств по Пакту. Ссылки на отсутствие необходимых средств не могут приниматься во внимание, так как ІІакт накладывает на участников обязательство принимать необходимые меры “в максимальньх пределах имеющихся ресурсов". Если рассматривать Пакт как документ не создающий такого минимального обязательства, то он во многом утрачивает свой смысл.

Фраза Пакта "в максимальньгх пределах имеющихся ресурсов" относится как к ресурсам самого государства, так и к ресурсам, которые оно может получить от международного сообщества в рамках международной помощи и сотрудничества. В соответствин с п. 1 ст. 2 Пакта государства обязуются "в индивидуальном порядке и в порядке международной помощи и сотрудничества, в частности в экономической и технической областях, принять... меры...”. К числу международньх мер, способствуюших осуществлению социально-экономических прав ст. 23 Пакта относит "оказание технической помощи" и ряд других мер.

На состоявшееся в марте 1995 г. в Копенгагене Всемирной встрече на высшем уровне в интересах социального развития представители 187 государств обратились к правительствам с призывом объединить усилия в целях содействия социальному развитию во всем мире и возложили осуществление Копенгагенской Деклараџии и Программы действий на ЭКОСОС. Многие из обязательств, зафиксированньх в этих документах, уже включены в Пакт, другие содержат новые аспекты и представляют собой попыгку дальнейшего развития экономических, соџиальных и культурных прав. Будущее за прогрессивным развитием этой категории прав человека и отмечаемое пятидесятилетие Всеобщей декларации должно придать этому процессу новый импульс. 